\title{
Mediat ja sivistys mediakasvatuksen näkökulmasta
}

\author{
$y$ \\ Media määrittää arkeamme ehkä enemmän kuin \\ arvaammekaan. Millaisessa mediamaailmassa liikumme \\ ja kuinka siihen suhtaudumme?
}

KYSYMYS KOSKEE KAIKENIKÄISIÄ. Näyttää siltä, että lapset aloittavat median säännöllisen seuraamisen noin kolmen vuoden iässä, ja mediapuberteetti alkaa varhain. Uudet mediat ovat kuitenkin uusia niin lapsille, nuorille kuin aikuisille. Siksi aikuiskasvattajan on syytä pohtia omaa mediasuhdettaan. Kannattaa miettiä, millainen ote itsellä on: joutuuko varsinkin uusien medioiden kohdalla moraaliseen paniikkiin vai omakko luontevan mediakriittisen asenteen, joka antaa mahdollisuuden hyödyntää medioiden antia.

Latinalais-anglosaksista alkuperää oleva sana media (yksikössä medium) kotiutui 1990-luvulla suomen kieleen. Alun perin monikollinen muoto media on suomen kielessä saanut sekä kokonaiskäsitemerkityksen että yksikkömerkityksen, jonka monikko- muoto puolestaan on mediat. Tässä puheenvuorossa käytetään laaja-alaista määritelmää: media on kommunikaation mahdollistava ilmaisumuoto ja/ tai ilmaisuväline.

Usein toistettu näkemys, että lapset ja nuoret ovat taitavampia medioiden käyttäjiä kuin aikuiset, on harhainen. Tekninen näppäryys medioiden käytössä on vain lähtökohta eikä se korvaa sisältöjen hallintaa. Optimaalisena tavoitteena voidaankin pitää kommunikatiivista kompetenssia, sisällön ja muodon yhteisen hallinnan tasapainoista suhdetta.

Mediakulttuurin muotoutumista ohjaa sekä teknologian että sisältöjen kehitys (Merilampi 2014a). Molemmissa tapauksissa mediakulttuuri syntyy vastavuoroisesti; sitä luovat niin käyttäjät kuin tuottajatkin, niin lähettäjät kuin vastaanottajatkin. Ei siis voi 
syyttää yksin medioita kehnoista sisällöistä, oudoista rakenteista tai tuotantotavoista: jos huonolaatuisille mediatuotteille ja -palveluille ei olisi kysyntää, ei niitä tehtäisi eikä markkinoitaisi.

\section{KOMMUNIKAATIO JA KONEET}

Kommunikaatio on sanaetymologiansa (communicare, kommuuni) mukaisesti aina kaksi- tai monisuuntaista, vuorovaikutteista. Kansainvälisissä vertailuissa suomalaista kommunikaatiota on pidetty lähtökohtaisesti hitaana, haluttomana ja estyneenä verrattaessa esimerkiksi Etelä-Eurooppaan (Lewis 1996). Kommunikaatio kasvokkain saattaakin olla suomalaiselle vaikeampaa kuin monille muille kansallisuuksille, mutta uudet viestintävälineet ehkä rohkaisevat aktiivisemmin osallistumaan. Välineet etäännyttävät ja mahdollisesti sitä kautta rohkaisevat aitoon itseilmaisuun ja kansalaisaktiivisuuteen.

Viestinnän historiassa on kautta aikojen kauhisteltu uusia kommunikaatiokoneita. Antiikin Kreikassa sekä Sokrates että Platon olivat huolissaan uusista kommunikaatiovälineistä: ajattelija kadottaa ajatuksensa, jos merkitsee sen pergamentille; puhetaito katoaa kirjoitustaidon yleistyessä. Platon kuitenkin otti kirjoitustaidon käyttöönsä, koska sen edut ylittivät sen haitat. Pelko uusia viestimiä kohtaan onkin aina osoittautunut turhaksi. Mediateknologian kehityksen myötä ihmiskunta on vain saanut uusia tapoja kommunikoida keskenään.

Tosin intuitiivisesti on nähtävissä, että ensimmäisen kerran jo 1920-luvulla sosiologien (mm. W.F.Ogburn 1922 teoksessaan Social change with respects to culture and original nature) esittämä teoria kulttuuriviiveestä (cultural lag) on jossain määrin toteutunut käytännössä: mediateknologia kehittyy nopeasti, mutta inhimillinen tajunta ja yhteiskunnallinen mediaymmärrys hitaammin.

\section{MEDIAT JA AIVOTUTKIMUS}

Aivotutkimus on pyrkinyt osoittamaan, kuinka erilaisten mediatyökalujen käyttö vaikuttaa merkittävästi aivotoimintoihin; informaation välittymisen tavoilla on yhteyttä ajattelun rakenteisiin. Edelleen tarvitaan paljon tutkimusta ja metatutkimuksia, jotta tuo yhteys voidaan verifioida.
Monet aivotutkijat ovat todenneet, että aivoissa on ruuhkaa (mm. Carr 2010 ja Baron 2008). Tutkijat ovat ryhtyneet yhä useammin puhumaan infoähkystä, infomaniasta, tietotsunamista, älyllisestä ylikuormituksesta ja aivoväsymyksestä silloin kun internet kasaa aineistoa lyhytkestoiseen muistiin, josta se ei siirry ymmärrettynä pitkäkestoiseen muistiin. Kun jatkuvana virtana ottaa vastaan ja itse välittää viestejä - eli tekee montaa asiaa samanaikaisesti (multitasking) - aivot väsyvät nopeasti.

Multitaskaus, "moniajo" liitetään usein lasten ja nuorten kykyyn käsitellä informaatioita. Informaation prosessointitavat saattavatkin olla olennainen selittäjä sille, kuinka eri ikäpolvet medioihin suhtautuvat. Informaatiota voidaan prosessoida tiedoksi sekä rinnakkain että peräkkäin sekä nopeasti selaillen että hitaasti syventyen. Jos/kun informaation välittymisen tavoilla on vaikutusta ajattelun rakenteisiin, on ajattelu moniulotteisempaa, jos kykenemme rytmiä vaihdellen molempiin prosessointitapoihin.

Mediakulttuuriin laajemmin liittyen on esitetty, että älykkyysosamäärä on noussut medioiden määrän lisääntyessä (Johnson 2006). Johnsonin mukaan nuorten älykkyys on kasvanut 2000-luvulla median ja teknologian kehityksen myötä; populaarikulttuurin kuluttaminen kehittää kognitiivisia kykyjä. Johnson ei kuitenkaan ole neurologi vaan mediatutkija, joten tuloksia tulee tarkastella mediakulttuurikontekstissa.

Älykkyystutkimusten ongelmana on, että tietokäsitys muuttuu koko ajan. Perinteinen staattinen tietokäsitys on saanut rinnalleen teknologiainnovaatioista syntyneen uudenlaisen dynaamisen tiedon käsitteen, jossa normatiivisuus ja standardisuus ovat löyhentyneet. Nykyisellä tietokäsityksellä on läheinen yhteys sellaisiin käsitteisiin kuin sosiaalinen osaaminen, sosiaaliset ja monikulttuuriset taidot.

\section{VISUAALISUUS JA VERBAALISUUS}

Kaikkea inhimillistä toimintaa voidaan tarkastella kielenä, jolla on omat sääntönsä, sanastonsa ja kielioppinsa. Ihmisellä on käytössään kaksi perusperiaatteellista tapaa hankkia tietoa maailmasta: sanallinen ja kuvallinen. Niiden mahdollisuudet ovat erilaisia, mutta ne ovat toisilleen välttämättömiä. 
Mediassa visuaalisuus on kulttuurista valtavirtaa, joka joidenkin tutkimusten mukaan (Future Work Skills 2020) korostuu entisestään niin, että informaation vahvasti visuaalisesta luonteesta tulee normi. Kyseisen tutkimuksen mukaan tulevaisuuden työntekijöiden tulee hallita uusien medioiden lukutaito (new-media literacy), jotta heillä on kykyä kriittisesti arvioida ja kehittää sisältöä, joka käyttää uusia mediamuotoja sekä kykyä ymmärtää uutta mediaekologiaa.

Kuvan ja sanan liitto (ks. esim. Mikkonen 2005) muodostuu siitä, että visuaalisella aistitiedolla ja hahmotuksella on suurta merkitystä verbaalisessa viestinnässä. Kun opitaan jäsentämään ympäristöhavaintoja täsmällisiksi moniaistimuksellisiksi mielikuviksi, opitaan havaitsemaan, tulkitsemaan ja ymmärtämään - ajattelemaan.

\section{VIIHTEEN VAKAVUUS}

Asioiden viihteellistä ja asiallista esittämistä ei ole tarpeen asettaa vastakkain. Leikinomaisuus ja viihteellisyys asiallistuvat iän myötä, mutteivät koskaan katoa. Elämänläheisyys, havainnollisuus ja ymmärrettävyys muodostavat yhdessä monimutkaisen semioottisen kysymyksen.

Vaikka asia olisi viihteellisesti esitetty, se voi olla ajatteluumme tehokkaasti vaikuttavaa, sekä hyvässä että pahassa. Me käytämme medioita moneen eri tarkoitukseen. Alkuvaiheessa media toimii usein leikinomaisena välineenä, jossa tärkeintä on kokeilu ja rajojen etsiminen. Seuraavassa vaiheessa väline yleensä otetaan hyötykäyttöön.

Tosin median edustama viihdeteollisuus ei useinkaan luo uusia näkemyksiä, vaan poimii, kierrättää ja vahvistaa jo olemassa olevia asenteita. Mediaviihde on monella tapaa vahvasti kaupallista. Mainonta ja markkinointi ovat niin oleellinen osa esimerkiksi netinkäyttöä, että monen on vaikeaa erottaa epäkaupalliset viestit kaupallisista, samoin lehtien journalistiset jutut ilmoituksista.

\section{MONIA TODELLISUUKSIA}

Tyypillinen piirre nykyiselle mediamaisemalle on, että median ja sen ulkopuolisen todellisuuden välisen rajan hahmottaminen on käynyt entistä vaikeammaksi, lähes mahdottomaksi. Nykykulttuurimme al- kaa olla läpeensä medioitunutta. Digitaalisen verkkomedian läsnäolo korostuu ja verkostomaiset mediat kasvattavat merkitystään ihmisten arjessa. Mediavälineiden reaaliaikaisuus ja niiden mahdollistama yhteisöllisyys sekä läpinäkyvyys ovat madaltaneet mediaja reaalimaailman välistä aitaa.

Virtuaalitodellisuudesta voidaan perustellusti käyttää termiä digitaalinen todellisuus. Digitodellisuudella tarkoitetaan mediavälineen avulla luotua kokemusta, joka voi mentaalisesti korvata reaalitodellisuuden. Se mahdollistaa vuorovaikutuksen kokijan ja synteettisesti luodun todellisuuden välillä.

Kun pohditaan massamedian sisältökysymyksiä, on tiedettävä, että media ei kykene heijastamaan peilin tavoin yhteiskunnallista todellisuutta, vaan luo itse omilla ehdoillaan rakentamiaan todellisuuksia. Todellisuus, joka medioiden kautta välittyy, on lähinnä todellisuuden vaikutelma. Kyky noiden vaikutelmien analysointiin saattaa olla avain yhteiskunnallisten ongelmien ratkaisuihin.

Mediassa faktat ja fiktiot, todet ja tarut, sekoittuvat keskenään. Uutisten ohella kulkee koko ajan fiktiivisiä tarinoita, huhuja ja juoruja. Vauhti on tietoverkkojen aikakaudella kova: jutut kulkevat ympäri maapallon hetkessä. Uutinen ja viihde kulttuurisina ilmiöinä usein limittyvät keskenään.

Herääkin kysymys, kuinka ratkaistaan mediayhteiskunnassa informaation määrää ja kommunikaation laatua koskeva dilemma. Esimerkiksi informaation ääretöntä määrää edustavassa verkossa ilmiöt ja asiat voidaan kuvata tarkasti, mutta niiden painoarvot ja merkitykset eivät erotu, vaan suuret ja pienet asiat saattavat näyttää yhtä tärkeiltä. Tarvitaan kommunikaation laatua edustavaa suodatusta.

\section{MEDIAKASVATUKSEN MAHDOLLISUUKSIA}

Mediakasvatuksella tarkoitetaan tässä yhteydessä jokaisen kansalaisen kykyä käyttää medioita tilannekohtaisesti, tarkoituksenmukaisella tavalla sekä opiskelussa, työssä että vapaa-aikana.

Sivistäminen on opettamista vaativampaa; se on luovaa ja ennustamatonta (Niemelä 2011). Sivistyksen välittäjän tulee huomioida oppijoiden ainutlaatuisuus ja yksilöllisyys. Sivistämisessä toimii hyvin vertaisoppiminen, jossa oppijat käyvät dialogia tois- 
tensa kanssa. Sivistyminen kuuluu kaikille aktiivisille ja omatoimisille demokraattisen yhteiskunnan kansalaisille.

Sivistymiseen liittyy läheisesti luovuuden käsite. Kvartaalitalouden tehotuotannon ja luovuuden vaatiminen samanaikaisesti on skitsofrenista (Uusikylä 2012). Viipyilevä luovuus pitäisi saada kunniaan kaikessa oppimisessa; vasta silloin henkinen kasvu johtaa sivistykseen. Luova yksilö on ajattelussaan ja toiminnassaan sujuva ja joustava, eikä etene kaavamaisen jäykästi, vaan osaa luovia. Hänellä on syntetisointikykyä ja analyyttistä kyvykkyyttä.

Sivistys on perustavanlaatuinen ilmiö; älyllinen uteliaisuus ja syvällinen tietämys tuovat intellektuaalista vapautta. Mediakulttuurin perusta on se, että ihmisten enemmistö on tietoinen mediamenneisyydestä. Keskustelu medioissa ja medioista on mahdollista silloin, kun ihmisillä on yhteisesti jaettua tietoa (shared knowledge). Mediakasvatuksella tuetaan ennakkoluulottomuutta, suvaitsevaisuutta ja epävarmuuden sietokykyä.

Mediakasvatus on kommunikatiivista, keskustelevaa ja omiin pohdintoihin aktivoivaa (Merilampi 2014a). Se on kriittistä, analysoivaa ja valikoivaa mediankäyttöä. Se antaa työkaluja todellisuuden mielekkääseen jäsentämiseen sekä terveen ihmiskuvan ja maailmankuvan luomisaineksia - minä maailmassa, maailma minussa.

\section{MEDIAKIELITAIDON ABC}

\section{Medialukutaito}

Lukutaidolla on käsitteenä ja ilmiönä suhteellisen muuttumaton paikka kasvun, kasvatuksen, kehittymisen ja oppimisen ideaalina. Lukutaitoa on kautta aikojen pidetty sivistyksen avaintekijänä.

Medialukutaito on terminä tunnettu, mutta käsitteenä sen käyttö on hataraa ja epäselvää. Vaikka medialukutaidosta puhutaan paljon, vasta mediakirjoitustaito on toimivan subjektin vapautumisen väline; on osattava toimia sekä viestien vastaanottajana että lähettäjänä.

Vuonna 2016 käyttöön otettavassa perusopetuksen opetussuunnitelmassa (Opetushallitus 2014) määritellään tulevaisuuden lukutaidoksi moniluku- taito, jolla tarkoitetaan lähinnä tieto- ja viestintätekniikan opetuskäyttöä. Vaarana on, että medioiden rooli ihmisten arjessa jää pohtimatta ja vaille huomiota toisin kuin aikaisemmissa perusopetuksen opetussuunnitelmissa (1994 ja 2004), joissa aihekokonaisuuksina olivat viestintäkasvatus ja viestintä- ja mediataidot.

Euroopan komissio on laajoissa hankkeissaan pyrkinyt arvioimaan tulevaisuuden mediakompetensseja (Celot 2009). Kompetenssi-termiä käytetään usein medialukutaidon synonyymina. Mediakompetenssilla (mediaosaaminen, mediaosaamisvalmius) tarkoitetaan lähinnä tehtävän suorittamisessa tai ongelman ratkaisemisessa tarvittavia tietoja, taitoja ja asenteita sekä kykyä käyttää niitä vuorovaikutteisella tavalla mediakontekstissa.

UNESCO on kuvannut medialukutaidon ja informaatiolukutaidon kompositiota sellaisin määrittein kuin peruslukutaito, digitaalinen lukutaito, TVT-lukutaito ja internet-turvataidot, kirjastolukutaito, uutisten lukutaito ja kulttuuridiversiteetti (Global Media and Information Literacy 2013). Käsite hajaantuu niin moneen suuntaan, että aikamoisesta entropiasta lähdetään liikkeelle silloin kun yritetään määritellä median ja lukutaidon välisiä sivistyssuhteita.

\section{Mediakielitaito}

Suomessa mediakielitaidon käsitteen on nostanut väitöskirjassaan esiin Suoninen (2003). Käsite ei kuitenkaan saanut jalansijaa mediakasvatuksen kentässä. Termi on nyt nostettu esiin kuviossa 1. kuvatussa mediakielitaidon portaikossa (Merilampi 2014a, 142-157).

Kielitaitoon liittyy aina kielen sanaston, rakenteen, kieli- ja lauseopin sekä kielen muiden ominaisuuksien hallinnan ohella kyseisen kulttuurin tuntemus. Mediakielitaidon hallinta viittaa mediamaailman käyttämän kielen hyvään tuntemiseen, mutta myös mediakulttuurin ilmiöiden ymmärtämiseen ja mediakulttuuriin osallistumiseen. Mediakielitaitoa tarvitaan niin kaupallisen mainonnan ja markkinoinnin kuin yhteiskunnallisen mediavaikuttamisen tulkinnassa ja niihin vastaamisessa.

Mediakielitaito-käsite pyrkii kuvaamaan erilaisten taitojen ja käytänteiden kokonaisuutta, joka ohjaa 
henkilön tapaa käyttää medioita ja tulkita mediasisältöjä omassa elämässään. Se on kyky käyttää medioita tarkoituksenmukaisella tavalla, ymmärtää medioiden kieltä ja tulkita mediasisältöjä sekä kriittisesti että niistä nauttien. Mediakielitaidolla on analogioita luonnollisen kielen oppimiseen.

Mediakielitaidon osa-alueet ovat yleisesti tunnettua mediakasvatuksen sisältöä. Tieto mediavaihtoehdoista liittyy siihen, mitä medioita on olemassa, mitä milläkin voi tehdä ja mihin mikäkin soveltuu. Medioiden muotokielen tuntemukseen puolestaan liittyvät sekä tuotantotekniikoiden tuntemus että tarinarakenteen ymmärtäminen, samoin lajityyppien tunteminen.

Mediakielitaitoa on kyky erottaa fakta fiktiosta ja tuntea niiden yhdistelmät $($ fact + fiction $=$ faction), samoin mediamaailman logiikan ja etiikan jonkintasoinen tuntemus sekä median rakenteiden ja konglomeraattien, monialayhtymien tunnistaminen.

Mediakielitaitoon liittyy läheisesti myös retoriikka-ajattelu. Tieto medioiden käyttämien ilmaisumuotojen tekniikoista edesauttaa tiedostamaan kriittisemmin medioiden tapoja rakentaa merkityksiä. Siinä valinta on keskeinen käsite, samoin kuvan retoriikan tunteminen.

Uusi mediatekniikka vaatii ja samalla houkuttelee esiin uudenlaisia mediakielitaitoja. Tablettitietokoneet ja digitaaliset lukulaitteet saattavat olla välineitä, joilla pitkien rauhallisten tekstien lukuharrastus vahvistuu. Toisaalta jatkuva verkkolukeminen on tehnyt lukemisesta pikaista silmäilyä, toteuttanut jonkinlaista vilkaisuviestinnän ideaa.

Uusilla viestintätavoilla on todennäköisesti vaikutusta myös kirjoittamiseen. On syntynyt muun muassa Twitter- ja tekstiviestityyli, joilla monen mielestä tulee hyvin ymmärretyksi. Uusien taitojen ja tekniikoiden kautta voidaan tukea myös vanhoja luku- ja kirjoitustaitoja, monipuolistaa itseilmaisua ja synnyttää uusia kommunikointitapoja.

\section{Mediakielitaidon portaikko}

Mediakielitaidon portaikon laadinta perustuu kirjoittajan pitkäaikaiseen kokemukseen traditionaalisen luku- ja kirjoitustaidon opettamisen sykleistä, mutta nyt niitä tarkastellaan mediaekologisessa ympäristössä.
Askelmia voidaan kulkea sekä alhaalta ylöspäin että ylhäältä alaspäin ja myös liikkua portaalta toiselle mediakielitaidon harjaannuttamisvaiheesta riippuen. Metaforan tehtävänä on analyyttisesti kuvata laajaalaisen mediakielitaidon välttämättömiä osatekijöitä.

\section{MEDIAKIELITAIDON ASKELMAT}

\section{SOSIOKULTTUURISET \\ VALMIUDET \\ - kulttuurin muutokset \\ - kulttuurien välinen dialogi \\ - verkottuminen}

\section{EETTIS-MORAALISET ARVOVALINNAT}

- kommunikatiivinen kompetenssi

- n-etiikka ja n-etiketti

- aidot kokemukset vs. mediaaliset

\section{UUTTA LUOVA KULTTUURINEN KYKY:} MERKITYSTEN YMMÄRTÄMINEN

JA TULKINTA

- analysointi ja argumentointi = mediakriittisyys

- ilo ja elämyksellisyys, taidenautinnot

- voimaannuttava

\section{TUOTTAJA/JULKAISUVALMIUDET}

- kirjoittaminen, kuvittaminen, äänittäminen, dramaturgia, design

- vaikuttaminen ja osallisuus

- itseilmaisu ja luovuus

\section{VASTAANOTTOVALMIUDET}

- eri tekstilajityyppien (genret) tunnistaminen

- merkkijärjestelmät ja niiden yhdistelmät: kuvat, sanat, äänet, ikonit, graafit $=$ monimediaiset tekstit

\section{MOTIVAATIO}

- älyllinen uteliaisuus ja perusvalmius abstraktiin ajatteluun

- traditionaalisen luku- ja kirjoitustaidon perusteet

- kontekstuaalisuus: oikea väline ja sisältö omiin tarpeisiin

- koodauksen perusteet

- saavutettavuus ja tekniset perusvalmiudet, näppäintekniikka

Kuvio 1. Mediakielitaidon portaikko. 


\section{Motivaatio}

Portaikon ensimmäinen askel osoittaa, että mediakielitaidon oppimismotivaation synnyttämiseksi ja syntymiseksi tarvitaan älyllistä uteliaisuutta ja perusvalmiuksia abstraktiin ajatteluun. Perinteisen luku- ja kirjoitustaidon perusteet on hallittava. Kaiken perustana on medioiden saavutettavuus ja pääsy aineistoihin. Motivaatio kasvaa siitä, kun havaitaan mihin kaikkeen teknologia yltää.

Tekniikan kieli kehittyy koko ajan. Mediakeskusteluissa käytetään paljon vaikeita ja vieraita termejä, uudissanoja, jotka saattavat hämmentää ja laskea motivaatiota tarttua laitteisiin. Tieto- ja viestintätekniikan sanaston pitäisi tulla sen verran tutuksi kaikille, ettei sillä voi hämätä ja hämmentää ei-tietotekniikkaorientoituneita oppijoita.

Vuonna 2016 voimaan tulevaan perusopetuksen suunnitelmaan (OPH 2014) on liitetty koodauksen perusteiden opettaminen. Siitä saattaa tulla omalta osaltaan uusi avain mediakielitaidon lähtökohtien ymmärtämiseen.

Teknologiadeterministit usein unohtavat, että immateriaaliset aspektit, älyllinen sisältö ja ilmaisulliset ulottuvuudet mediakielitaidossa ovat yhtä tärkeitä kuin teknologiset osatekijät. Siksi on syytä olettaa, ettei ole mielekästä jäädä mediakielitaidon alimmalle portaalle.

\section{Vastaanottovalmiudet}

Viestien vastaanotossa portaikon toisessa askelmassa on tunnistettava median eri genrejä eli lajityyppejä. Näin vastaanottaja ymmärtää viestien sisällöt ja osaa tulkita ne tarkoituksenmukaisella tavalla. On myös osattava lukea monimediaisia tekstejä ja tunnistaa erilaisia merkkijärjestelmiä sekä pystyttävä tekemään päätelmiä narratiivisten sanomien sisällöstä.

Viestien vastaanotossa tarvitaan erittelytaitoa: tiedon erottamista uskomuksista, faktan ja fiktion erojen ja yhtäläisyyksien tunnistamista, mainonnan erottamista toimituksellisesta aineistosta eli kykyä erottaa kaupallinen sisältö journalistisesta.

\section{Tuottaja/julkaisuvalmiudet}

Mediakielitaidossa aktiiviseen omaan tuottamiseen tarvitaan kirjoitustaitoa, kuvitustaitoa ja taitoa tehdä dramaturgioita ja designia. Näin pääsemme mukaan osallisuuden ja vaikuttamisen kulttuuriin. Omia viestejä välitetään interaktiivisesti. Siksi onkin syytä puhua medioiden käyttäjistä, ei kuluttajista.

Mediakielitaidon kolmannella portaalla opitaan kuvallisen ilmaisun perusperiaatteita kuvakulman valinnasta ja kuvan rajauksesta otosten rytmiikkaan. Kuvallisen ilmaisun aakkoset opitaan samaan tapaan kuin kirjoitustaito, systemaattisesti opiskellen.

Hyvä mediakielitaito tukee meissä jokaisessa elävää vahvaa itseilmaisun ja uuden luomisen tarvetta, jonka tyydyttämiseen sofistikoituneet nykymediat vastaavat mitä parhaiten. Kunkin omat luovuuden lähteet löytävät ilmaisunsa harjaantuneen mediakielitaidon avulla ja kautta.

\section{Merkitysten ymmärtäminen ja tulkinta}

Neljännellä askelmalla hallitaan kriittinen mediakielitaito. Kriittisen mediakielitaidon oppiminen on olennaisen tärkeää, kun ihmiset opettelevat tulemaan toimeen mediaympäristönsä kanssa. Kun opimme lukemaan, arvioimaan, tulkitsemaan ja vastustamaan mediamanipulaatiota, pystymme toimimaan adekvaatisti vallitsevassa mediakulttuurissa. Samalla kykymme vaikuttaa omaan mediaympäristöömme kasvaa ja pystymme itsekin tuottamaan uusia mediamuotoja ja sisältöjä. Kriittinen mediakielitaito opettaa kriittistä suhtautumista median representaatioihin ja diskursseihin, mutta myös painottaa median käyttöä elämyksien ja itseilmaisun välineenä sekä yhteiskunnallisen osallistumisen keinona.

Mediakritiikin traditio Suomessa on ohut. Joukkoviestinnän ja journalismin tutkimusta hallitsi pitkään vertauskuva mediasta ikkunana todellisuuteen, ja 1960-luvulla televisio tarjosikin monella tapaa jännittävän ikkunan sellaisiin maailmoihin ja kulttuureihin, joista oli kyetty vain haaveilemaan.

Usko ikkunametaforaan on himmennyt ja ajatus hylätty. Nyt media näyttäytyy meille pikemminkin koneistona, joka tuottaa kuvien, sanojen, äänien ja ikonien kautta erilaisia tulkintoja todellisuudesta. Samalla nuo median tuottamat tulkinnat vaikuttavat takaisin siihen todellisuuteen, mistä ne kertovat.

Uusi tekniikka on muuttanut tietoa epäpersoonalliseksi. Samalla kun tiedon käyttö muuttuu yhä 
henkilökohtaisemmaksi, tiedon lähteet käyvät vähemmän ilmeisiksi. Vuorovaikutteiset järjestelmät antavat käyttäjälle mahdollisuuden itse valita informaation muoto, laatu ja määrä. Kuitenkaan järjestelmät eivät tarjoa mahdollisuutta tarkistaa tiedon luotettavuutta tai asettaa sitä oikeisiin yhteyksiinsä. Siinä tarvitaan mediakielitaitoa, vastaanottajan omaa tulkintaa.

Arkipuheessa kriittisyys liitetään virheiden etsintään ja negatiivisiin kannanottoihin. Kriittinen ajattelu on kuitenkin myönteistä ja tuottavaa toimintaa, joka liittyy sekä älyyn että tunteeseen (ks. esim. Warnick \& Inch 1999). Kriittisen ajattelun avulla kyseenalaistetaan tavanomaisuudet. Ajattelutapa ei ole käynyt vanhanaikaiseksi, vaan se on merkittävä osa tulevaisuuden yleissivistystä.

Uutta tietoa etsivä ja itseään uudistava medialukija kohtaa tekstin avoimesti, mutta kyseenalaistaa samalla mediatekstin tarkoitusta ja sisältöä käyttämällä hyväksi aiempia tietojaan ja kokemuksiaan. Kriittinen medialukija pyrkii myös paljastamaan tekstiin kätkettyjä piilomerkityksiä ja suhteuttamaan tekstin tietoa omiin käsityksiinsä, arvostuksiinsa ja tavoitteisiinsa.

Avoimissa verkoissa tietoa ei ymmärretäkään tieteellisesti todistetuksi, universaaliksi ja tieteenaloihin sidotuksi, vaan kontekstuaaliseksi: tarkoitusta, tarvetta ja käyttäjiä palvelevaksi. Tiedon totuudellisuuden, pätevyyden ja luotettavuuden arviointi jää näin vastaanottajalle. Vapaus ja avoimuus tarjoavat medialukijalle kaikki mahdollisuudet erilaiseen tietoon, mutta samalla lukijan on itse kyettävä arvioimaan tiedon merkitys ja arvo.

Media tuottaa valtavan määrän aineistoa, joka voidaan määritellä taiteeksi, viihteeksi ja elämystuotannoksi. Kyky valita esimerkiksi verkosta olennaisia tekstejä vaatii oppijalta paljon järjestelmällistä ja pitkäjänteistä harjoittelua.

Sekä uusien että vanhojen medioiden tarkastelussa tarvitaan kriittisyyttä ja lähdekriittisyyttä. Informatiivisen viestinnän ja viihteellisen tuotannon ero on yhä häilyvämpi. Erilaisten mediatekstien mediakielitaitoinen käyttäjä oppii erottamaan tulkinnan ja todistusaineiston, käsittelemään ristiriitatietoa ja myös muuttamaan omia tietorakenteitaan.

\section{Sosiokulttuuriset valmiudet}

Sosiokulttuuristen valmiuksien hallinta korostaa mediakielitaidon sosiaalista ja globaalia luonnetta. Tätä kuvataan portaikon viidennellä askelmalla.

Kulttuurien välistä dialogia käydään paljon medioiden kautta ja avulla. Media laajasti ymmärrettynä voidaan käsittää uudeksi tavaksi tarkastella maailmaa ja humaania olemassaoloa ( $\mathrm{mm}$. Kalantzis \& Cope 2012). Tällöin media ei ole mikään sektori, vaan uusi tapa pohtia yhteiskunnallista toteutumista ja ihmisten keskinäistä kanssakäymistä. Kun media nähdään symbolimerkein tapahtuvaksi inhimilliseksi vuorovaikutukseksi, hyvä mediakielitaito tekee ihmiset kykeneviksi tuohon vuorovaikutukseen.

Kuten mediakielitaidon portaikko osoittaa, ei ole olemassa yhtä ainoaa mediakielitaitoa, vaan lukuisa määrä erilaisia tapoja ja tasoja käyttää mediakieltä. Taito ei periydy, vaan jokainen sukupolvi itse rakentaa oman mediakielitaitonsa. Syntyminen digitaaliselle aikakaudelle ei automaattisesti takaa riittävää mediakielitaitoa. Tätä taustaa vasten puhe diginatiiveista on harhaista.

Kalantzis \& Cope (2012) nostavat teoksessaan Literacies esiin uuden mediaympäristön vaatimuksena kommunikaatiomuodot oral, visual, audio, gestural ja spatial. He korostavat laaja-alaisten luku- ja kirjoitustaitojen hallinnan ja sosiokulttuurisen diversiteetin ymmärtämisen merkitystä sekä työpaikoilla että laajemmin yhteiskunnassa. Lähestymistapa kuvaa hyvin mediakielitaidon käsitettä, vaikka kirjoittajat eivät kyseistä termiä käytä.

Näyttää siltä, että mediakielitaidon kehittyminen liittyy ihmisten kanssakäymisen joustavuuteen, suvaitsevaisuuteen, mielenkiinnon kohteiden monipuolistumiseen, muutoshalukkuuteen, aloitteellisuuteen ja innovaatiokykyyn. Mediat solmiutuvat yhä laajemmin ihmisten elämäntapaan ja elämänhallintaan kaikilla tasoilla. Tätä taustaa vasten mediakielitaito voidaan nähdä "sivistyksellisenä perusoikeutena” tulevaisuuden mediayhteiskunnassa.

\section{Eettis-moraaliset arvovalinnat}

Viidennen portaan tavoitteena on kommunikatiivinen kompetenssi: on hallittava median muoto ja sisältö niin, että ne tukevat toisiaan. Jotta kyetään sekä muodon että sisällön eettis-moraalisiin arvovalintoihin, on 
jossain määrin tunnettava mediankäyttäjien toiveet ja tarpeet. Samalla opitaan kysymään, mitä mediat eivät tarjoa tai käsittele, mistä medioissa ei puhuta.

Saksalainen yhteiskuntafilosofi Jürgen Habermas on esittänyt kommunikatiivisen kompetenssin idean. Mediasivistyksessä voidaankin vaatia habermaslaista viestinnällisen kyvykkyyden opettamista. Sillä tarkoitetaan tässä mediatekstien sisällöllisen hallinnan lisäksi niiden välittymisen taidon hallintaa. Ei siis riitä, että hallitsee sen mitä viestitään, median käyttäjän on myös hallittava miten viestitään sekä eettisenä aspektina ennen kaikkea miksi, millaisin tarkoitusperin.

Luonnollisesti on hallittava hyvin netiikka ja netiketti, nettikäyttäytymisen perussäännöt, käsitys omista ja muiden oikeuksista. Näin lähestytään aitojen kokemusten ja mediaalisten kokemusten yhteistä arvopohjaa: arki ja media-arki kohtaavat ennennäkemättömällä tavalla.

Verkossa on useita omanlaisiaan maailmoja. Siellä on suuria toreja, joissa ihmiset avoimesti kohtaavat, mutta myös pimeitä kujia, joissa elää ja voimistuu ääriajattelu. Virtuaalimaailman moraali ei voi olla erilainen kuin se fyysisen maailman moraali, jossa me toinen toisemme kohtaamme.

\section{MEDIASIVISTYS UUSHUMANISMINA}

Suomalaisessa mediakasvatustutkimuksessa on korostunut anglo-amerikkalainen suuntaus. Osittain se selittyy median kansainvälisellä tuotannolla ja toisaalta englannin kielen valtavirralla. Samalla kuitenkin suomalainen kouluopetus pitkälti pohjaa 1800-luvun saksalaiseen Bildung-sivistyskäsitykseen. Onkin tutkimusta vinouttavaa, että Medienerziehung on saanut niin vähän jalansijaa suomalaisessa mediakasvatustutkimuksessa (Merilampi 1997).

Humanismiksi voidaan kutsua elämänasennetta, jossa ihminen käyttää erottelukykyään, lähestyy ongelmia laaja-alaisesti ja hankkii tietoa vapauttaakseen itsensä väärien uskomusten, vallankäytön ja pelon kahleista. Humanistis-yhteiskuntatieteellinen sivistys tarjoaa yksilöille aineksia samastua erilaisiin yhteisöihin ja siten rakentaa itselleen identiteettiä.

Mediasivistys voidaan nähdä uushumanistisena. Se ulottuu ihmisen kulttuuria luovan kyvyn (von Wright 1987) kaikkiin kolmeen haaraan - tieteeseen, taiteeseen ja filosofiaan.

Eurooppalaisessa nykykeskustelussa ( $\mathrm{mm}$. Pérez Tornero \& Varis 2010) uushumanismi saa sellaisia määritteitä kuin kulttuuriperinnön uudelleen rakentaminen, uudet universaalit kielet, uudet olemassaolon muodot, yleishumaanit arvot sekä uudenlainen luovuus ja estetiikka.

Samat määrittelyt liitetään myös mediateknologian kuvaamiseen. Intellektuaalisesta edelläkävijyydestä puhuttaessa vanha humanismi edustaa kosmopoliittisuutta, mutta uusi humanismi nostaa esiin universaalit oikeudet ja velvollisuudet.

Mediakasvatuksellinen uusi humanismi (Merilampi 2014a, 179-184; Merilampi 2014b) pyrkii murtamaan teknologiauskon maailmaa tulkittaessa; sen sijaan se asettaa inhimillisen persoonan toiminnan lähtökohdaksi. Uushumanismin tavoitteena on moninaisuuden ja kulttuurien monimuotoisuuden tunnustaminen ja sivilisaatioiden välinen vuoropuhelu.

On välttämätöntä ymmärtää, että kulttuurituotteet ja mediapalvelut välittävät identiteettejä, arvoja ja merkityksiä eikä niitä siten voida tarkastella pelkästään kulutustuotteina. Uushumanistisessa ajattelussa yhdistetään teknologinen tehokkuus ja tuottavuus sivistykseen ja kriittisyyteen. Uushumanistinen mediasivistys pyrkii kumoamaan tiedon vallan nostamalla rinnalle elämyspohjaisuuden. Keskeiseksi nousee ajattelun joustavuus, mikä merkitsee valmiuksia nähdä asioita uudella tavalla. Semioottiseen jakoon (Broms 1985) perustuvan länsimaisen rationaalin loogis-lineaarisen ajattelun rinnalle pyritään siten tuomaan itäinen, symbolinen, myyttis-runollinen ajattelu.

Mediasivistystä ei nähdä välinepainotteisesti eikä tekniikkakeskeisesti, vaan sisältökeskeisesti. Tätä taustaa vasten tiedon, tunteen ja tahdon vastakkainasettelu on mahdotonta, ne on asetettava rinnakkain. Kognitioiden ja emootioiden jyrkkä toisistaan erottaminen on mahdotonta. Samoin tahdon ja tietämisen erottaminen; tahto ymmärtää voidaan nähdä yhdeksi ja samaksi ilmiöksi.

Voidaankin puhua kognitiivista emootioista, arkikielellä tunneälystä. Mediasivistys parhaimmillaan kyseenalaistaa jaon yhtältä tunteettomaan tietoon ja toisaalta mieltä vailla olevaan tunteeseen. Kognitiota 
ei voida puhtaasti eristää ja liittää vain tietoon ja tieteeseen, samoin kuin ei emootiota voida liittää vain taiteisiin, etiikkaan ja uskontoon.

Tulevaisuuden tutkimuksen linjausten mukaan tulevaisuus ei tule, se ei ole luonnonvoima kuten tulva tai maanjäristys, vaan me teemme sen omien valintojemme kautta. Yhtenä tulevaisuuden valintana voisi olla mediasivistyksen vaaliminen mediakielitaidon avulla.
Ritva-Sini Merilampi
$K T$, Opetusneuvos (OKM) emerita

\section{LÄHTEET}

Baron, N. S. (2008). Always On. Language in an Online and Mobile World. New York: Oxford University Press.

Broms, H. (1985). Alkukuvien jäljillä. Kulttuurin semiotiikkaa. Juva: WSOY.

Carr, N. (2010). The Shallows. What the Internet Is Doing to Our Brains. New York - London: W.W. Norton \& Company.

Celot, P. (2009). (toim.) Study on Assessment Criteria for Media Literacy Levels. A comprehensive view of the concept of media literacy and an understanding of how media literacy level in Europe should be assessed. Brussels: The European Comission. Information Society and Media DG. Media and Media Literacy Unit.

Future Work Skills 2020. Institute for the Future for the University of Phoenix Research Insititute. Palo Alto, CA. 2011. www.iftf.org

Global Media and Information Literacy. Assessment Framework. Country Readiness and Competencies. Paris: UNESCO 2013.

Hintikka, K. A. (2015). Internet, sosiaalinen media ja yleissivistävä opetus Suomessa. Koulun tulevaisuus. Futura 2/2015. Tulevaisuuden tutkimuksen seura ry.

Johnson, S. B. (2006). Kaikki huono on hyväksi. Miten populaarikulttuuri tekee meistä älykkäämpiä. Helsinki: Terra Cognita.

Kalantzis, M. \& Cope, B. (2012). Literacies. New York: Cambridge University Press. http://Literacies.com

Lewis, R. D. (1996). Kulttuurikolareita. Keuruu: Otava.

Merilampi, R.-S. (2014a). Mediakasvatuksen perusteet. Helsinki: BTJ Finland.

Merilampi, R.-S. (2014b). Mediakasvatuksella tulevaisuuden mediayhteiskuntaan. Julkaisussa Top Ten X Tarinoita ja teesejä median tulevaisuudesta 1/2014, 44-50. Tulevaisuuden tutkimuksen seura ry.
Merilampi, R.-S. (2012). Mediasivistystä vahvistamassa. Tietotaitotalkoot pedagogisena mallina. Helsinki: Kyriiri Oy. www.ttlry.fi/tietotaitotalkoidenmateriaalipankki

Merilampi, R.-S. (1997) Lernen in der Informationsgesellschaft erfordert geistige Flexibilität. Julkaisussa Informationsgesellschaft. Schriftenreihe der Bundesanstalt für Arbeitsschutz und Arbeitsmedizin. Dortmund/Berlin.

Mikkonen, K. (2005). Kuva ja sana. Kuvan ja sanan vuorovaikutus kirjallisuudessa, kuvataiteessa ja ikonoteksteissä. Gaudeamus Kirja. Tampere: Tammer-Paino Oy.

Niemelä, S. (2011). Sivistyminen. Sivistystarve, pedagogiikka ja -politiikka pohjoismaisessa kansansivistystraditiossa. Helsinki: Kansanvalistusseura.

Pérez Tornero, J. M. \& Varis, T. (2010). Media Literacy and New Humanism. UNESCO Institute for Information Technologies in Education.

Perusopetuksen opetussuunnitelman perusteet 2014. Opetushallitus. Määräykset ja ohjeet 2014:96.

Suoninen, A. (2003). Mediakielitaidon jäljillä. Lapset ja nuoret valikoivina mediankäyttäjinä. Väitöskirjamoniste. Jyväskylän yliopisto. Taiteiden ja kulttuurin tutkimuksen laitos. Nykykulttuurin tutkimuskeskus.

Uusikylä, K. (2012) Luovuus kuuluu kaikille. PSkustannus. Juva: Bookwell Oy.

Warnick, B. \& Inch, E.S. (1999). Critical Thinking and Communication. The Use of Reason in Argument. New York: Macmillan Publishing Company.

von Wright, G.H. (1987). Tiede ja ihmisjärki. Suunnistusyritys. Keuruu: Otava. 